\title{
Frost heave and thaw settlement of initially saturated-slurried and compacted-saturated materials
}

\author{
Snehasis Tripathy ${ }^{1, *}$, Osama Mahdi Al-Hussaini ${ }^{2}$, Peter John Cleall ${ }^{1}$, Stephen William Rees ${ }^{1}$, and Han-Lin Wang ${ }^{1}$ \\ ${ }^{1}$ School of Engineering, Cardiff University, Queen's Buildings, West Grove, Newport Road, Cardiff CF24 3AA, UK \\ ${ }^{2}$ Department of Civil Engineering, University of Kufa, Kufa, Iraq
}

\begin{abstract}
Soils and industrial waste in various geotechnical engineering applications are expected to experience freezing and thawing processes in various regions of the world where the winter and summer temperatures fluctuate between sub-zero and positive ambient temperatures. In this study laboratory tests were undertaken on three materials (Speswhite kaolin, Pegwell Bay soil and a cement kiln dust). A custommade test set up was used to carry out the laboratory tests involving freezing and thawing processes. Initially saturated-slurried and compacted-saturated samples of the selected materials were subjected to one cycle of freezing and thawing to study the influence of material type and initial conditions on the onedimensional frost heave and thaw settlement. The test results showed that the type of material and the initial conditions of the materials prior to the freezing process influenced the frost heave, frost heave rate, velocity of water flow, segregation potential, and thaw settlement. Compacted-saturated materials showed a tendency to exhibit a greater magnitude of frost heave as compared to their saturated-slurried counterparts.
\end{abstract}

\section{Introduction}

Studies associated with the impact of seasonal climatic processes involving freezing and thawing on the engineering behaviour of soils are extremely relevant due to their extensive use in a wide range of civil engineering applications. Soils modified by various admixtures, and industrial wastes may be exposed to sub-zero and positive temperatures during winter and summer months in various regions of the world. The volume change behaviour of such materials as influenced by freezing and thawing provide crucial information on the long-term stability of a variety of geo-infrastructure (pavement, railway formation, retaining wall, shallow foundation).

The freezing process may affect all soil types, but usually has a significant impact on frost susceptible soils. The main factor associated with the frost susceptibility of soils is the grain-size distribution [1]. When soils with significant fine-fractions are subjected to freezing, frost heave (volume increase due to formation of ice within the soil system) occurs as a result of two simultaneous processes, namely $(i)$ the pore water in the soil freezes in situ and (ii) the water from the unfrozen soil, or from an external source, is drawn to the segregation freezing front where it freezes at sub-zero temperatures, leading to the development of ice lenses and further heave [2]. On thawing, the ice melts and changes phase to water. If the ground has heaved, there will be excess water present which must drain away. The rate at which water is released is controlled by thermal and permeability considerations [3]. An increased water content in supporting layers during thawing weakens pavement structures due to a reduction in the bearing capacity of the soils [4]. Clayey soils with higher plasticity properties possess high water holding capacity and may exhibit significant frost heave and thaw settlement. An increase in the hydraulic conductivity and a decrease in the shear strength are some issues related to freeze-thaw cycling of soils [5-6].

The fabric and structure of soil systems are influenced by the particle size and initial compaction conditions (water content and dry density) [7]. The main objective of this investigation was to explore the impact of initial conditions (initially saturated-slurried and compacted saturated) on the one-dimensional volume change behaviour of various materials when subjected to one cycle of freezing and thawing.

\section{Materials and methods}

The investigation was carried out on three different materials, namely a kaolinite-rich clay (Speswhite kaolin), a frost susceptible natural soil collected from Pegwell Bay, UK (Pegwell Bay soil), and a cement kiln dust collected from a local (South Wales, UK) cement industry. The properties of the selected materials are shown in Table 1.

A custom-made test set up was used to carry out the laboratory tests involving freezing and thawing. The test setup (Fig. 1) is comprised of a polyvinyl chloride (PVC) column cell assembly (a step-flanged inner cell/specimen mould - internal diameter $103.3 \mathrm{~mm}$ and height $259 \mathrm{~mm}$, and an outer cell - internal diameter $120.8 \mathrm{~mm}$ and

Corresponding author: TripathyS@ cardiff.ac.uk 
height $247 \mathrm{~mm}$ ), a Vortex Tube connected to a top cooling chamber to control the freezing temperature at the top of specimen, an air supply source, four numbers of $\mathrm{S}$ series linear variable displacement transformers (LVDTs) to measure displacements of specimen and inner cell (measurement range $=50 \mathrm{~mm}$, linearity $=$ $0.2 \%$, resolution $=0.3 \mu \mathrm{m}$, and operating temperature range $=-40$ to $+120^{\circ} \mathrm{C}$ ), RS Pro K Type thermocouples (four located on the inner cell at distances of 4.5 (TC 1), 29.5 (TC 2), 54.5 (TC 3) and $63.5 \mathrm{~mm}$ (TC 4) from the top of the specimen and two within the cooling chamber (TC0)) (measurement range $=-50$ to $+250{ }^{\circ} \mathrm{C}$, response time $=0.7$ seconds, and accuracy $= \pm 1.5^{\circ} \mathrm{C}$ ), a porous stone, a water reservoir, a thermal insulation jacket $(30$ mm-thick rock-wool layer covered with a $3.7 \mathrm{~mm}$ thick reflective foil), and a data acquisition system to monitor the temperature and deformation with an elapsed time during both freezing and thawing processes.

Table 1. Properties of the materials used in this study.

\begin{tabular}{|c|c|c|c|}
\hline Properties & $\begin{array}{l}\text { Speswhite } \\
\text { kaolin }\end{array}$ & $\begin{array}{l}\text { Pegwell } \\
\text { Bay soil }\end{array}$ & $\begin{array}{c}\text { Cement } \\
\text { kiln dust }\end{array}$ \\
\hline Specific gravity & 2.61 & 2.69 & 2.72 \\
\hline Particle size & $\begin{array}{c}\text { Clay-size- } \\
93.6 \%, \text { silt- } \\
\text { size-6.4\%, } \\
\text { sand- } 0 \% \\
\end{array}$ & $\begin{array}{c}\text { Clay-size- } \\
8.4 \% \text {, silt- } \\
\text { size- } 84.3 \% \text {, } \\
\text { sand-7.3\% } \\
\end{array}$ & $\begin{array}{c}\text { Clay-size- } \\
0 \%, \text { silt- } \\
\text { size-70\%, } \\
\text { sand-30\% }\end{array}$ \\
\hline Liquid limit (\%) & 68.5 & 29.5 & 41 \\
\hline Plastic limit (\%) & 42 & 19.2 & 27 \\
\hline $\begin{array}{c}\text { Shrinkage limit } \\
(\%)\end{array}$ & 32.7 & 16.0 & 21.0 \\
\hline $\begin{array}{c}\text { Unified soil } \\
\text { classification } \\
\text { system } \\
\end{array}$ & $\mathrm{CH}$ & $\mathrm{CL}$ & ML \\
\hline $\begin{array}{c}\text { Mineral } \\
\text { composition }\end{array}$ & $\begin{array}{l}\text { Kaolinite and } \\
\text { illite }\end{array}$ & $\begin{array}{l}\text { Quartz, } \\
\text { calcite and } \\
\text { dolomite }\end{array}$ & $\begin{array}{l}\text { Calcite and } \\
\text { silica }\end{array}$ \\
\hline $\begin{array}{c}\text { Frost } \\
\text { susceptibility }\end{array}$ & Medium & $\begin{array}{l}\text { Medium to } \\
\text { high }\end{array}$ & $\begin{array}{c}\text { Medium to } \\
\text { very high }\end{array}$ \\
\hline $\begin{array}{c}\text { Compaction } \\
\text { conditions: } \\
\text { water content } \\
\text { and dry density }\end{array}$ & $\begin{array}{c}30 \%, 1.42 \\
\mathrm{Mg} / \mathrm{m}^{3}\end{array}$ & $\begin{array}{c}19 \%, 1.69 \\
\mathrm{Mg} / \mathrm{m}^{3}\end{array}$ & $\begin{array}{c}24.2 \% \\
1.25 \\
\mathrm{Mg} / \mathrm{m}^{3}\end{array}$ \\
\hline
\end{tabular}

The outer cell is fixed to a solid PVC base that in turn is mounted on a stable platform. The outer cell accommodates a hollow acrylic cylinder at the bottom to create the water reservoir. An acrylic disc with holes is attached to the top of the cylinder. The porous stone rests on top of the acrylic disc. The specimen mould is positioned to rest on the acrylic disc. A difference in the outer diameter of the specimen mould $(115.3 \mathrm{~mm})$ and the internal diameter of the outer cell enables accommodating the cables of the thermocouples, and the specimen mould could move uniformly in an upward direction. The diameter and height of the specimens tested were $103.3 \mathrm{~mm}$ and $65 \mathrm{~mm}$ respectively. The available space above the specimen was such that upon placing the top cooling chamber $(101 \mathrm{~mm}$ diameter and $112 \mathrm{~mm}$ high), the top part of the chamber protruded out above the specimen mould by $4.5 \mathrm{~mm}$.

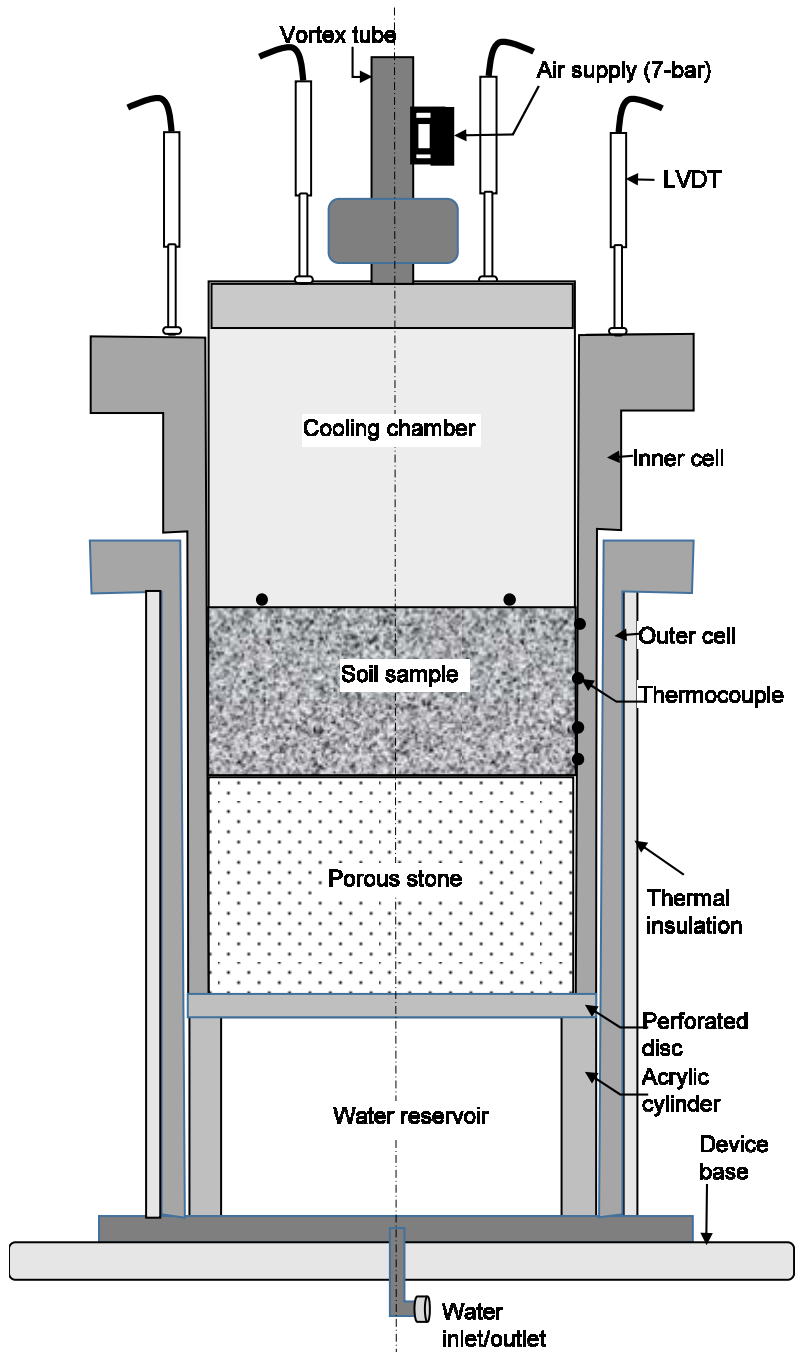

Fig. 1. A schematic of the test set up used.

Initially saturated slurried specimens with water contents equal to 1.2 times the liquid limit of the chosen material, were directly prepared within the test assembly. Compacted specimens (see compaction conditions in Table 1) were prepared separately in the specimen mould by static compaction method and the mould was then transferred and positioned in the test set up. The compacted specimens were saturated prior to the freezing stage. During the saturation process, water was supplied from an external water reservoir (not shown) through the inlet located on the PVC base.

A Vortex Tube allows cooling of the air [8]. Compressed air is fed transversely into the generation chamber of the Vortex Tube and made to spin by a generator. The air moves down the long tube in which hot air separates outwards and towards the wall of the tube due to the inertia of motion, whereas the cold air is pushed to the centre of the tube. A percentage of the hot air is made to exit, whereas the remaining air flows 
towards opposite end (cold end). A Vortex Tube was connected to the top cooling chamber. The top cooling chamber is a composite cylinder with a stainless-steel side and a $1.8 \mathrm{~mm}$ thick copper base. A $12.5 \mathrm{~mm}$-thick PTFE disc with six air vents, each $10 \mathrm{~mm}$ in diameter, is attached firmly to the top open end of the stainless cylinder. The air supply to the Vortex Tube during a test was from a 7-bar air compressor line. The pressurised air was made to exit the top chamber via the air vents.

In this investigation, the temperature at the top of the specimen was lowered to $-19{ }^{\circ} \mathrm{C} \pm 0.5{ }^{\circ} \mathrm{C}$ during the freezing process and was maintained for $24 \mathrm{hr}$. Such negative temperatures are common during harsh winters in many regions of the world. The thawing process occurred at the ambient laboratory temperature. During the tests, the deformation and temperature data were collected every minute. Trial tests were carried out to determine the deformation corrections that were required to be applied in actual tests. The self-weight of the cooling chamber exerted a vertical pressure of $2.0 \mathrm{kPa}$ on the specimens. During the saturation and consolidation stages, the water table was at the top the specimens, whereas during freezing and thawing stages the water table was at the bottom of the specimens. The temperature of the supplied water was $21 \pm 2{ }^{\circ} \mathrm{C}$.

\section{Results and discussion}

\subsection{Initially saturated slurried materials}

Figure 2 shows the consolidation behaviour of the initially saturated slurried materials under a nominal pressure of $2.0 \mathrm{kPa}$. A smaller deformation of cement kiln dust as compared to the other materials is attributed to the effect of the cement phase reaction that formed bonding between particles [9]. The decrease in the heights of the specimens affected the positions of the thermocouples with reference to the top of the specimens that in turn were considered for presenting the results.

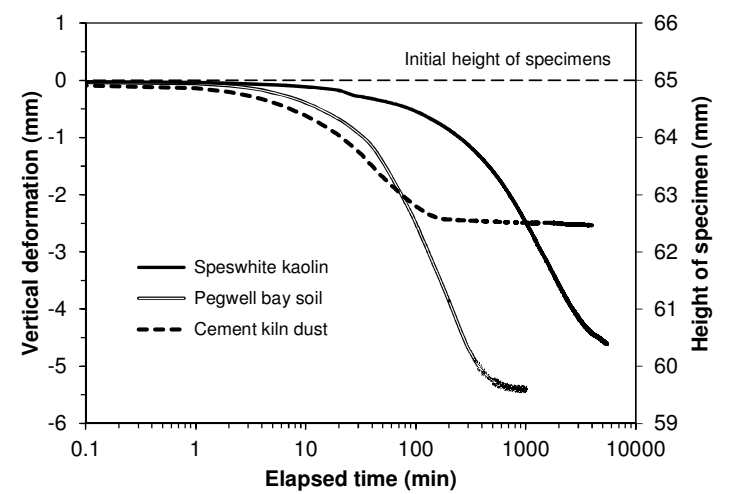

Fig. 2. Consolidation behaviour of the materials studied under a nominal vertical pressure of $2.0 \mathrm{kPa}$.

Typical elapsed time versus temperature and vertical deformation (vertical strain) during freezing and thawing processes for the initially saturated slurried specimen of Speswhite kaolin are shown in Fig. 3. The average values of the measured deformations by the LVDTs located on top of the cooling chamber is presented as deformation of the specimen, whereas the average values of the deformations measured by the LVDTs on the inner cell correspond to the deformation of the specimen mould. The test results of other materials showed similar trends, but with different magnitudes.
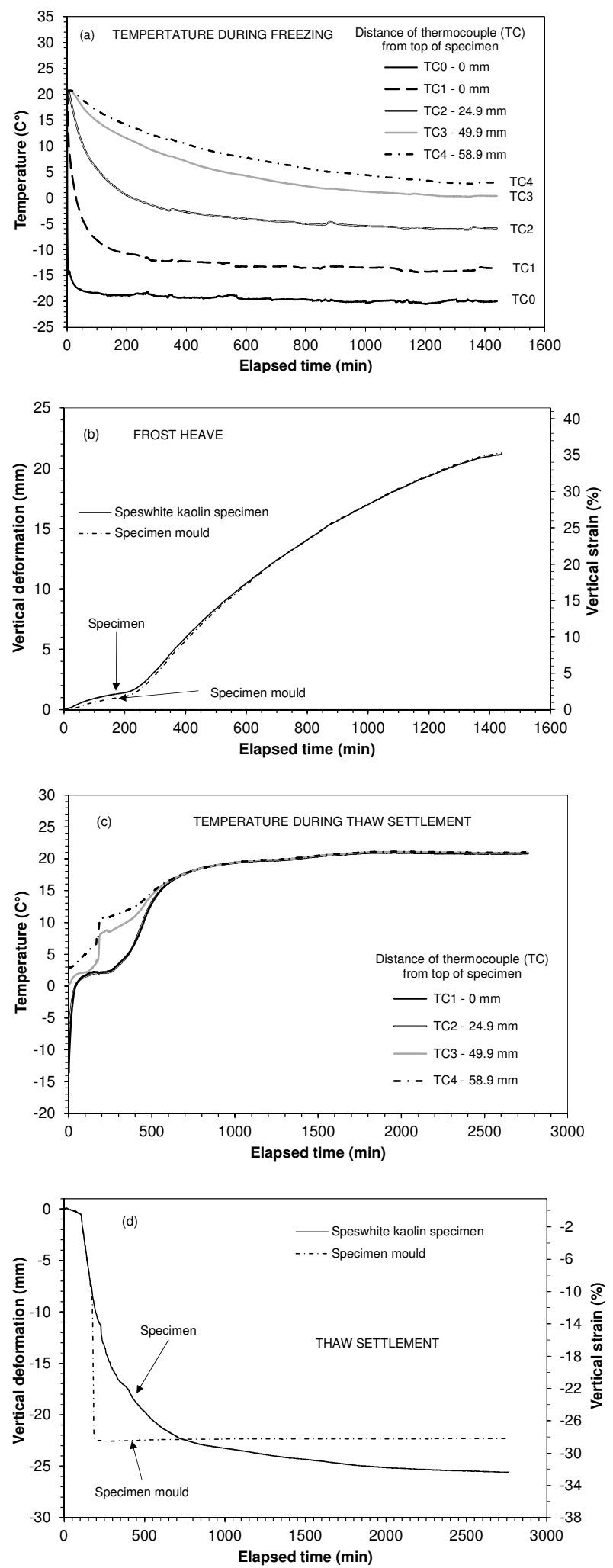

Fig. 3. Test results of initially saturated slurried Speswhite kaolin; (a) temperature during freezing, (b) frost heave, (c) temperature during thawing, and (d) thaw settlement. 


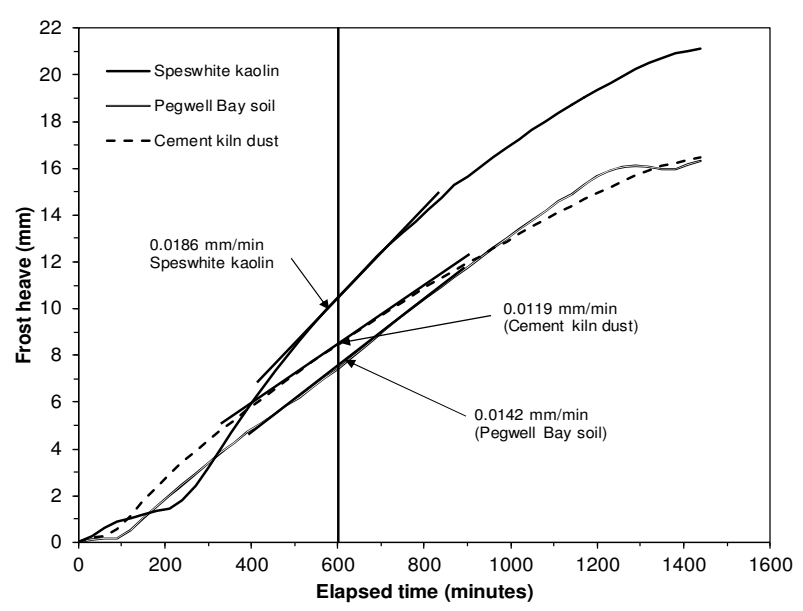

Fig. 4. Frost heave of in initially saturated slurried materials.

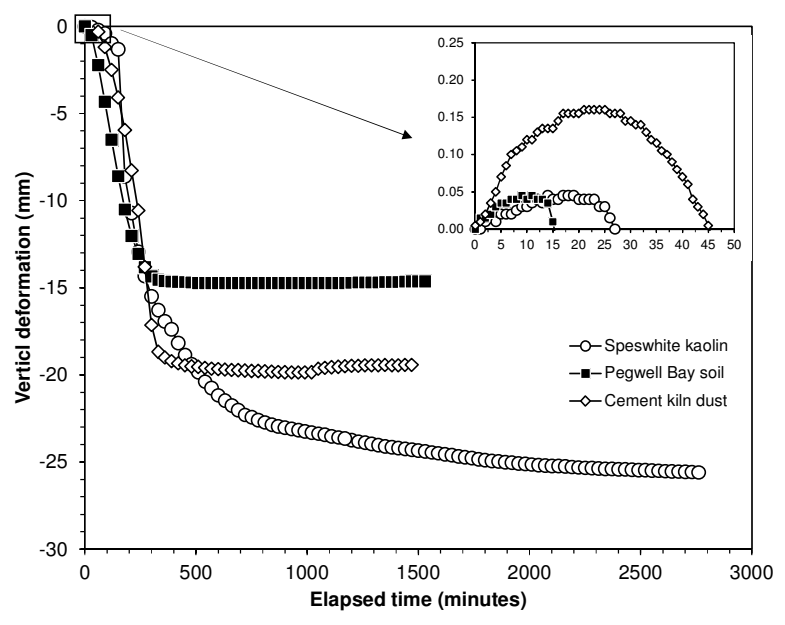

Fig. 5. Thaw settlement in initially saturated slurried materials.

The temperature at the top of the specimen decreased from the ambient laboratory temperature to sub-zero temperature within less than about twenty minutes, as indicated by the temperatures measured by TC0 (Fig. 3a). The temperature within the cooling chamber remained constant at about $-19{ }^{\circ} \mathrm{C}$ after more than about 60 min and until the end of the freezing stage. With an increasing depth of the specimens, the temperature decreased at the relatively slower rate (see the measured temperatures by TCs 1, 2, 3 and 4 in Fig. 3a).

A drop in the temperature at the top of the specimen caused ice formation at and near the top end of the specimens. The top end of the specimens remained adhered to the wall of the specimen mould (adfreezing effect [10]) by the ice formed which in turn did not allow the expansion of the specimens to occur in an upward direction due to the development of side friction. The expansion of the specimens occurred towards the bottom end (in the direction of least resistance). The deformation of both specimen and specimen mould were similar (Fig. 3b). A decrease in the temperature caused the development of frost heave in all the materials (Figs. $3 \mathrm{~b}$ and 4 ). The frost heave in the materials was on account of a change in the density of liquid water to the density of ice and formation of the ice lenses. Note that a change in the state of water from liquid to solid may cause a water volume expansion of only $9 \%$. The primary heave [11] was noticed for the specimen of Speswhite kaolin during the first three hours, whereas no frost heave was exhibited by other specimens for up to an hour of the tests. For certain materials an increase in the volume during freezing is balanced by the volume decrease due to the compression process [10]. Despite differences in the mineralogy and plasticity properties, both Pegwell Bay soil and cement kiln dust exhibited similar heave, whereas the frost heave was found to be greater for Speswhite kaolin.

The commencement of thawing stage took place by terminating the cold air supply to the cooling chamber. The drainage was free during this stage. It can be seen from Fig. $3 c$ that the temperature at all salient depths increased and attained the ambient laboratory temperature. The thawing process was accompanied by melting of ice within the specimens. The LVDTs positioned on the top cooling chamber and on the specimen mould showed downward movements indicating that thaw settlement had occurred (Fig. 3d). The test results showed that frictional resistance developed at the top end of the specimens due to the adfreezing was eliminated during the thawing process.

Figure 5 shows the thaw settlement of the materials. An additional heave occurred for all specimens immediately after the thawing process was commenced. Small magnitudes of heave during the initial phase of thawing for some soils have been reported [12]. The occurrence of heave during the thawing process is governed by a regulation mechanism in which case, as the water migrates from the thawed zone into the frozen zone, the ice and the unfrozen water in the frozen soil are no longer in equilibrium in terms of the energy state. Thus, ice formation occurs in the frozen portion of the thawing soil. An increase in soil volume during the initial phase of thawing may also be attributed to a decrease in effective stress resulting from an increase in the pore-water pressure [13]. The magnitude of thaw settlement remained for the materials as per the order: Speswhite kaolin, cement kiln dust and Pegwell Bay soil. The vertical strain during thawing was smaller than their counterparts during the freezing process.

\subsection{Compacted-saturated materials}

Compacted specimens of all the materials studied exhibited swelling upon saturation under a nominal pressure of $2.0 \mathrm{kPa}$ (Fig. 6). The vertical strain of Speswhite kaolin was found to be far greater than of the other materials that exhibited very minor swelling deformations.

Typical elapsed time versus temperature and vertical deformation (vertical strain) during freezing and thawing processes for the compacted-saturated specimen of Speswhite kaolin are shown in Fig. 7. A decrease in the temperature during the freezing process and an increase in the temperature during the thawing process were found to exhibit similar trends for the compacted specimen (Figs. 7a and c) as that occurred for initially 
the saturated slurried specimen. The deformation of the specimen and specimen mould were similar during freezing and thawing (not shown in Figs. $7 b$ and $d$ ). The test results of other materials showed similar trends, but with different magnitudes.

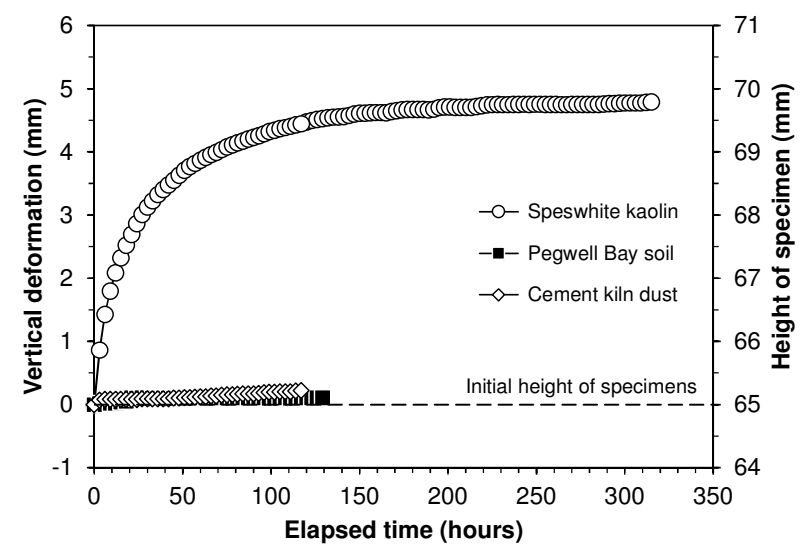

Fig. 6. Swelling of compacted specimens during saturation.

Figures 8 and 9 show the frost heave and thaw settlement of the compacted-saturated materials. The strains associated with the frost heave and thaw settlement of initially saturated slurried and compactedsaturated materials are compared in Table 2.

The impact of initial conditions of the materials on frost heave and thaw settlement is distinct (Table 2). For compacted-saturated Pegwell Bay soil and cement kiln dust, the strains associated with frost heave were greater than that of the initially saturated slurried materials. For these materials, the influence of initial conditions on thaw settlement was minor (remained within about $2 \%$ ). The strains associated with freezing and thawing of Speswhite kaolin were smaller in case of the compactedsaturated specimen as compared to that of the initially saturated slurried specimens.

The segregation potential $\left(S P_{\mathrm{t}}\right)[14]$ is defined as the ratio of water intake flux to temperature gradient (Eq. 1) and is considered as an important parameter that aids in assessing frost heaves in soils. The $S P_{\mathrm{t}}$ values for both initially saturated slurried and compacted-saturated specimens were calculated and compared in Table 3 . The $\mathrm{d} h / \mathrm{d} t$ values at steady state are shown in Figs. 4 and 8 . The $\Delta T_{\mathrm{f}}$ values were calculated based on the temperatures measured by thermocouples TC1 and TC4 and the corresponding heights of the specimens at 600 $\min$.

$$
S P_{\mathrm{t}}=v_{\phi} / \Delta T_{\mathrm{f}}=[(\mathrm{d} h / \mathrm{d} t) / 1.09] / \Delta \mathrm{T}_{\mathrm{f}}
$$

where $v_{\phi}$ is the total water velocity supplied to the active ice lens, $\Delta T_{\mathrm{f}}$ is the temperature gradient in the frozen fringe at steady state, $\mathrm{d} h$ is the change in height, $\mathrm{d} t$ is the change in time, $\mathrm{d} h / \mathrm{d} t$ is the heave rate.

It can be seen in Table 3 that the type of material and initial conditions influenced $v_{\phi}$ which either decreased or increased. The $S P_{\mathrm{t}}$ values of compactedsaturated specimens are found to be invariably greater than the initially saturated slurried specimens indicating conditions are more conducive for water inflow and ice lens formation in case of compacted materials.
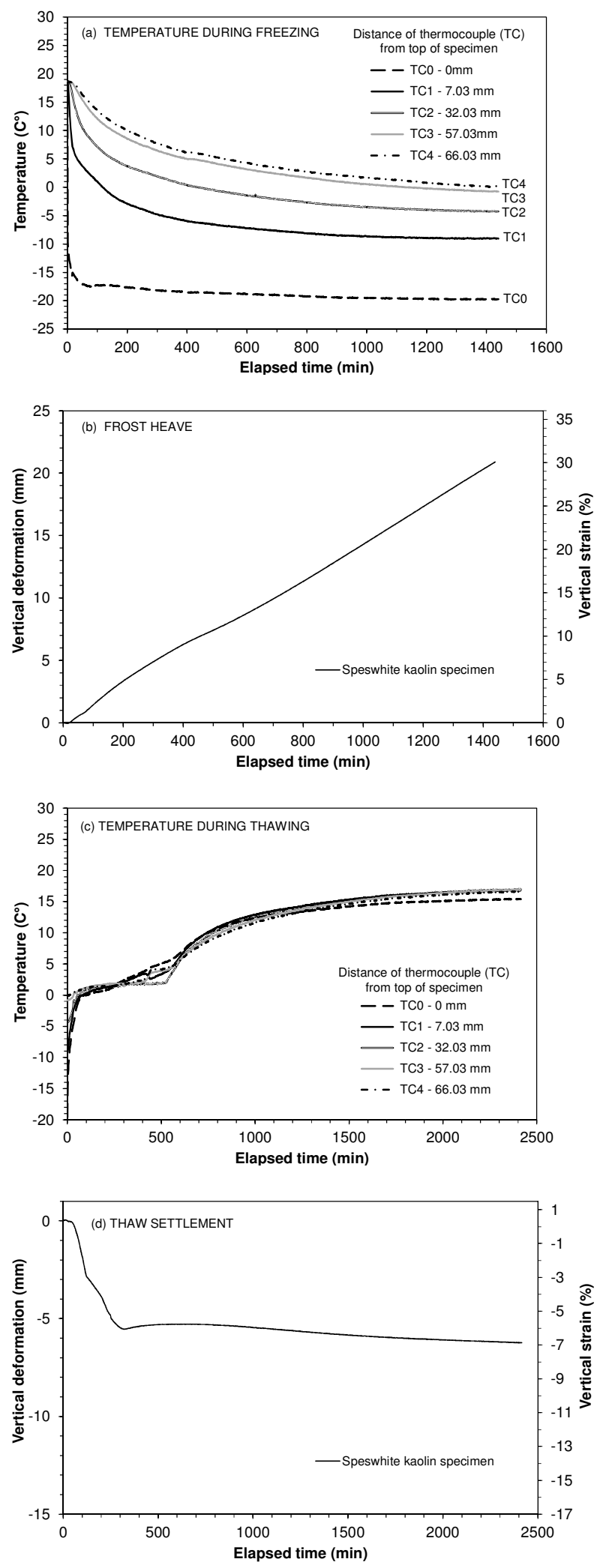

Fig. 7. Test results of compacted-saturated Speswhite kaolin; (a) temperature during freezing, (b) frost heave, (c) temperature during thawing, and (d) thaw settlement. 


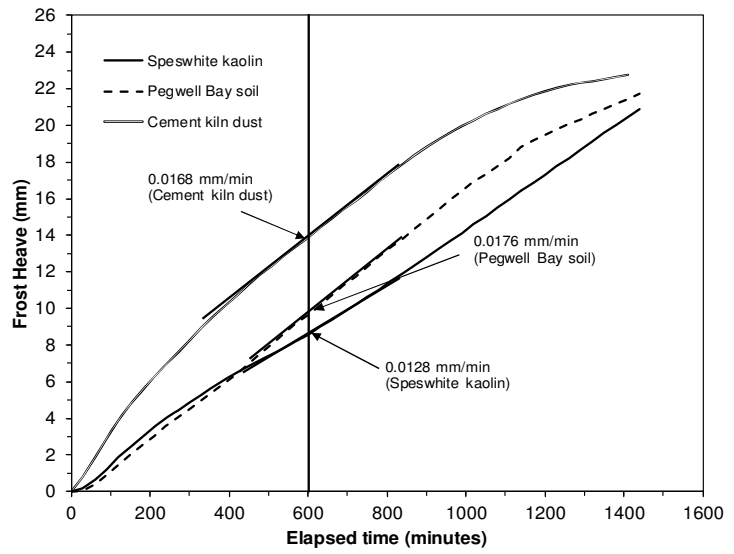

Fig. 8. Frost heave of compacted-saturated materials.

Table 2. Comparisons of heave and settlement of saturated slurried (SS) and compacted-saturated (CS) materials.

\begin{tabular}{|c|c|c|c|c|}
\hline \multirow{2}{*}{ Material } & \multicolumn{2}{|c|}{ Frost heave strain(\%) } & \multicolumn{2}{c|}{ Thaw settlement strain (\%) } \\
\cline { 2 - 5 } & $\mathrm{SS}$ & $\mathrm{CS}$ & $\mathrm{SS}$ & $\mathrm{CS}$ \\
\hline $\begin{array}{c}\text { Speswhite } \\
\text { kaolin }\end{array}$ & 35 & 30 & 31.8 & 6.8 \\
\hline $\begin{array}{c}\text { Pegwell } \\
\text { Bay soil }\end{array}$ & 27.3 & 33.3 & 18.7 & 20.4 \\
\hline $\begin{array}{c}\text { Cement } \\
\text { kiln dust }\end{array}$ & 26.2 & 35.1 & 24.6 & 22.6 \\
\hline
\end{tabular}

Table 3. Velocity of water flow, thermal gradient and segregation potential of the materials ( $\mathrm{SS}$ - saturated slurried, CS - compacted-saturated).

\begin{tabular}{|c|c|c|c|c|c|c|}
\hline \multirow{2}{*}{ Material } & \multicolumn{2}{|c|}{$\begin{array}{c}\text { Velocity of } \\
\text { water flow }\left(v_{\phi}\right. \\
(\mathrm{d} h / \mathrm{d} t) / 1.09) \\
(\mathrm{mm} / \mathrm{hr})\end{array}$} & \multicolumn{2}{|c|}{$\begin{array}{c}\text { Temperature } \\
\text { gradient }\left(\Delta T_{\mathrm{f}}\right) \\
\left({ }^{\circ} \mathrm{C} / \mathrm{mm}\right)\end{array}$} & \multicolumn{2}{|c|}{$\begin{array}{c}\text { Segregation } \\
\text { potential } \\
\left(S P_{\mathrm{t}}\right) \\
\left(\mathrm{mm}^{2} /{ }^{\circ} \mathrm{Chr}\right)\end{array}$} \\
\cline { 2 - 7 } & $\mathrm{SS}$ & $\mathrm{CS}$ & $\mathrm{SS}$ & $\mathrm{CS}$ & $\mathrm{SS}$ & $\mathrm{CS}$ \\
\hline $\begin{array}{c}\text { Speswhite } \\
\text { kaolin }\end{array}$ & 1.03 & 0.71 & 0.36 & 0.19 & 2.85 & 3.74 \\
\hline $\begin{array}{c}\text { Pegwell } \\
\text { Bay soil }\end{array}$ & 0.78 & 0.97 & 0.27 & 0.23 & 2.88 & 4.22 \\
\hline $\begin{array}{c}\text { Cement } \\
\text { kiln dust }\end{array}$ & 0.65 & 0.92 & 0.29 & 0.25 & 2.25 & 4.04 \\
\hline
\end{tabular}

\section{Conclusions}

This paper presented the freezing and thawing test results of initially saturated slurried and compactedsaturated specimens of Speswhite kaolin, Pegwell Bay soil and cement kiln dust. A custom-made testing device was used that enabled measuring the vertical deformations and the temperature at various salient depths during freezing and thawing.

The investigation showed that the magnitude of frost heave of compacted-saturated materials may well exceed that of initially saturated slurried materials. The velocity of water arriving at the advancing frost front increased and the temperature gradient in the frozen behind the frost front decreased leading to an increase in

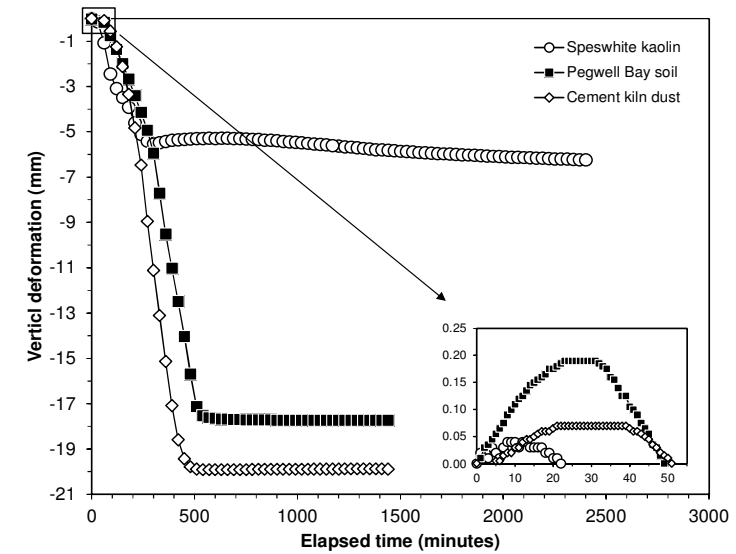

Fig. 9. Thaw settlement compacted-saturated materials.

the segregation potential for compacted-saturated materials. The thaw settlement was found to be influenced by material type and initial compaction conditions of the materials.

\section{Acknowledgements}

This study has been funded by the Engineering and Physical Sciences Research Council (EPSRC) as part of the Climate Adaptation Control Technologies for Urban Spaces (CACTUS) project.

\section{References}

1. E.J. Chamberlain, Frost Susceptibility of Soils: Review of Index Tests (Monograph 81-2. U.S. Army Cold Reg. Res. and Eng. Lab., Hanover, N.H, 1981)

2. J.-M. Konrad, ASTM Geotech. Test. J. 10, 1 (1987)

3. J. S. Harris, Ground freezing in practice (Thomas Telford, 1995)

4. E. Simonsen, U. Isacsson, Cold Reg. Sc. and Tech. 29 (1999)

5. D.Y Wang, W. Ma, Y.H. Niu, X.X. Chang, Z. Wen, Cold Reg. Sc. and Tech. 48, 1 (2007)

6. J.F. Kraus, C.H. Benson, A.E. Erickson, E.J Chamberlain, J. Geotech. \& Geoenv. Eng. 123, 3 (1997)

7. P. Delage, J. Graham, $1^{\text {st }}$ Int Conf on Unsat soils, Paris, Balkema 3 (1996)

8. J. Wang, X. Gao, S. Jiao, Int. Conf. on Energy and Env. Tech., Guilin, China (2009)

9. A. Buchwald, M. Schulz, Cement and concrete research 35, 5 (2005)

10. K.D. Eigenbrod, Can. Geotech. J. 33, 4 (1996)

11. K. O’Neill, R.D. Miller, Water Res. Res. 21, 3 (1985)

12. G. Cheng, E.J. Chamberlain, $5^{\text {th }}$ Int. Conf. on Permafrost, Norway (1988)

13. K.D. Eigenbrod, S. Knutsson, D. Sheng, J Cold Reg. Eng. 10, 2 (1996)

14. J.-M. Konrad, N.R. Morgenstern, Can. Geotech. J. 18, 4 (1981) 